Jurnal Health Sains: p-ISSN: 2723-4339 e-ISSN: 2548-1398

Vol. 2, No. 4, April 2021

\title{
HUBUNGAN KEBIASAAN KONSUMSI FAST FOOD DAN STRES TERHADAP SIKLUS MENSTRUASI PADA REMAJA PUTRI SMAN 12 KOTA BEKASI
}

\section{Benefita Rahma}

Sekolah Tinggi Ilmu Kesehatan Mitra Keluarga Bekasi, Jawa Barat, Indonesia Email: benefitarahma94@gmail.com

\begin{tabular}{|c|c|}
\hline ARTIKEL INFO & ABSTRACT \\
\hline $\begin{array}{l}\text { Tanggal diterima: } 5 \text { April } 2021 \\
\text { Tanggal revisi: } 15 \text { April } 2021 \\
\text { Tanggal yang disetujui: } 25 \\
\text { April } 2021 \\
\end{array}$ & $\begin{array}{l}\text { Adolescence is a period in which the development of } \\
\text { hormones will fluctuate and can cause menstruation in } \\
\text { women. The factors which affect the menstrual cycle are } \\
\text { ujnhealthy eating habbits, unbalanced nutritional content in }\end{array}$ \\
\hline $\begin{array}{l}\text { Keywords: } \\
\text { menstruation cycle; fast food } \\
\text { consumption; stress levels }\end{array}$ & $\begin{array}{l}\text { fast food, to namely high calories, high fat, high sugar and } \\
\text { low fiber. The fatty acid content in fast food affects } \\
\text { progesterone metabolism in the luteal phase of the menstrual } \\
\text { cycle. In addition, stress levels affect the menstrual cycle, at } \\
\text { times stress produces the hormone cortisol, the cortisol } \\
\text { hormone causes an imbalance in reproductive hormones, } \\
\text { resulting in disruption of the menstrual cycle. This study } \\
\text { aimed to analyze the relationship between fast food } \\
\text { consumption intakes and stress on the menstrual cycle in } \\
\text { Bekasi City 12th National Senior High School students. The } \\
\text { research method used was quantitative with a cross sectional } \\
\text { design. The research sample was students of Bekasi City } 12 \text { th } \\
\text { National Senior High School using simple random sampling } \\
\text { technique. Data were collected using menstrual cycle } \\
\text { questionnaires, PSS-10, and food frequency questionare } \\
\text { (FFQ). The results of the research from the results of the } \\
\text { bivariate analysis using the Chi-square test showed that } \\
\text { there was a significant relationship between fast food } \\
\text { consumption and the menstrual cycle among high school } \\
\text { students of } 12 \text { Bekasi City with a p-value of 0.003 and OR } \\
\text { 5.0. And there is also a significant relationship between } \\
\text { stress levels and the menstrual cycle in Bekasi City } 12 \text { th } \\
\text { National Senior High School students with a p-value of O.O05 } \\
\text { and OR 6.4. }\end{array}$ \\
\hline
\end{tabular}

\begin{abstract}
ABSTRAK
Masa remaja merupakan masa di mana perkembangan hormon akan naik turun dan dapat menyebabkan terjadinya menstruasi pada wanita. faktor yang mempengaruhi siklus menstruasi yaitu pola makan yang tidak sehat, kandungan gizi pada fast food tidak seimbang yaitu tinggi kalori, tinggi lemak, tinggi gula dan rendah serat. Kandungan asam lemak didalam makanan cepat saji mempengaruhi metabolisme progesteron pada fase luteal dari siklus menstruasi. Selain itu
\end{abstract}

$\begin{array}{ll}\text { How to cite: } & \text { Rahma, B (2021) Hubungan Kebiasaan Konsumsi Fast Food Dan Stres Terhadap Siklus Menstruasi } \\ & \text { Pada Remaja Putri Sman } 12 \text { Kota Bekasi. Jurnal Health Sains 2(4). } \\ & \text { http://jurnal.healthsains.co.id/index.php/jhs/article/view/151 } \\ \text { E-ISSN: } & 2723-6927 \\ \text { Published by: } & \text { Ridwan Institute }\end{array}$




\section{Kata Kunci:}

siklus menstruasi; konsumsi

fast food; tingkat stres

\begin{abstract}
tingkat stres mempengaruhi siklus menstruasi, saat stres menghasilkan hormon kortisol, Hormon kortisol menyebabkan ketidakseimbangan pada hormon reproduksi, salah satu akibatnya gangguan siklus menstruasi. Penelitian ini bertujan untuk menganalisis hubungan konsumsi fast food dan stres terhadap siklus menstruasi pada siswi SMAN 12 Kota Bekasi. Metode penelitian yang di gunakan kuantitatif dengan desain cross sectional. Sampel penelitian adalah siswi SMAN 12 Kota Bekasi menggunakan Teknik simple random sampling. Data di kumpulkan menggunakan kuisioner siklus menstruasi, PSS-10, dan food frequency questionare (FFQ). Hasil penelitian dari hasil analisis bivariat menggunakan uji Chi-square menunjukan bahwa Terdapat hubungan yang signifikan antara konsumsi fastfood dan siklus menstruasi pada siswi SMAN 12 Kota Bekasi dengan p-value 0,003 dan OR 5.0. Dan juga terdapat hubungan yang signifikan antara tingkat stres dengan siklus menstruasi pada siswi SMAN 12 Kota Bekasi dengan pvalue 0,005 dan OR 6,4 .
\end{abstract}

\section{Pendahuluan}

Masa remaja merupakan masa di mana perkembangan hormon akan naik turun dan dapat menyebabkan terjadinya menstruasi khusususnya pada wanita. Menurut (Perry, 2009) masa remaja adalah masa dimana terjadinya transisi dari masa kanak-kanak menuju dewasa, biasanya antara usia $13-20$ tahun, yang mengalami perubahan psikologi, kognitif, dan seksualitas. Menurut (Prihatanti, 2010) pada masa remaja muncul beberapa perubahan fisiologis yang kritis, dimana perubahan individu pada kematangan fisik dan biologis. Kematangan fisik remaja putri di lihat dari adanya perubahan-perubahan siklis pada alat kandungannya sebagai persiapan untuk kehamilan. Perubahan siklus yang di alami remaja menuju kematangan fisik tersebut adalah menstruasi.

Menstruasi adalah pendarahan akibat dari luruhnya dinding sebelah dalam rahim (endometrium). Lapisan endometrium dipersiapkan untuk menerima implantasi embrio. Jika tidak terjadi implantasi embrio lapisan ini akan luruh. Perdarahan ini terjadi secara periodik, jarak waktu antara menstruasi dikenal dengan satu siklus menstruasi (Purwoastuti, 2009). Siklus menstruasi adalah Jurnal Health Sains, Vol 2, No 3, April 2021 waktu sejak hari pertama menstruasi sampai datangnya periode menstruasi berikutnya. Umumnya, durasi siklus menstruasi adalah 28 hari, dengan lama menstruasi adalah 4 hingga 6 hari. Jumlah darah yang keluar pun rata-rata sebanyak 20-60 mililiter. Pada masa menstruasi terdapat beberapa gangguan yang terjadi pada masa menstruasi. Pertama, Polimenorea yaitu kondisi di mana panjang siklus menstruasi memendek dari panjang siklus normalnya yang kurang dari 28 hari persiklusnya. Kedua, yaitu oligomenorea yang merupakan panjang siklus menstruasi yang memanjang dari siklus normalnya atau lebih dari 35 hari. Ketiga, amenorea yaitu panjang siklus menstruasi yang memanjang yang tidak terjadinya pendarahan selama 3 bulan berturutturut.

Menurut WHO pada tahun 2012 prevalensi gangguan siklus menstruasi pada wanita remaja sebesar $45 \%$. Data Riskesdas pada tahun 2010 prevalensi gangguan siklus menstruasi pada wanita usia 10-59 tahun sebesar $13,7 \%$ dan $11,7 \%$ pada wanita usia 15 - 19 tahun di Indonesia. Sedangkan menurut data Dinas Kesehatan Kota Bekasi pada tahun 2014 menunjukan bahwa 46\% siswi memiliki masalah kesehatan reproduksi, yaitu siklus 
menstruasi tidak teratur tiap bulan, dan gangguan menstruasi seperti nyeri perut hebat, keputihan ataupun gatal di sekitar daerah kemaluan.

Salah satu faktor yang mempengaruhi gangguan siklus menstruasi yaitu pola makan yang tidak sehat. Kebiasaan sering mengkonsumsi fast food merupakan pola makan yang tidak sehat. Fast food adalah makanan cepat saji yang tergolong makanan tinggi lemak, tinggi natrium, tinggi gula tetapi kandungan serat dan vitaminnya rendah. Menurut (Banowati et al., 2011) kandungan gizi pada fast food tidak seimbang, jika di konsumsi terus menerus secara berlebih akan menimbulkan masalah gizi dan faktor resiko penyakit, seperti obesitas, gangguan kulit, penyakit degenerative dan gangguan siklus menstruasi. Menurut (Larasati \& Alatas, 2016) makanan saji memiliki kandungan gizi yang tidak seimbang yaitu tinggi kalori, tinggi lemak, tinggi gula, dan rendah serat. Kandungan asam lemak didalam makanan cepat saji mengganggu metabolisme progesterone pada fase luteal dari siklus menstruasi. Fast food yang biasanya di konsumsi diantaranya : burger, kentang goreng, fried chiken, hamburger. Konsumsi fast food sudah menjadi bagian dari gaya hidup di masyarakat Indonesia terutama pada remaja. Hal ini di perkuat oleh (Astuti \& Maggiolo, 2014) menunjukan bahwa yang paling paling banyak mengkonsumsi fast food adalah remaja. Dan pada penelitian Lili (2018) menunjukan adanya hubungan yang signifikan antara konsumsi fast food dengan siklus menstruasi.

Selain itu, ada hal lain yang mempengaruhi siklus menstruasi yaitu, tingkat stres. Tingkat stres juga menjadi hal yang sangat mempengaruhi siklus menstruasi, karena stres membuat rangsangan pada hypothalamus-pituitary-adrenal aksis sehingga menghasilkan hormon kortisol. Hormon kortisol menyebabkan ketidakseimbangan antara hormonal pada hormon reproduksi, salah satu dampaknya adalah perubahan siklus menstruasi. Hal ini di perkuat berdasarkan penelitian (Abdullah et al., 2014) di dapatkan hasil sebagian besar siswi mengalami stres sedang yaitu $46,8 \%$ dan siswi yang mengalami gangguan siklus menstruasi Polimenorea 13,8\%, Oligomenorea 24,5\% dan Aminorea 10,6\%.. dan penelitian (Pinasti \& Anggraini, 2012) menyebutkan bahwa dari 38 responden mengalami siklus menstruasi tidak normal sebanyak $57,6 \%$ dari yang mengalami stres.

Berdasarkan uraian latar belakang di atas, penulis tertarik untuk meneliti apakah terdapat hubungan antara kebiasaan konsumsi fast food dan tingkat stres terhadap gangguan siklus menstruasi di SMA 12 kota Bekasi.

Tujuan penelitian ini untuk mengetahui hubungan konsumsi makanan siap saji dan stress terhadap siklus menstruasi pada siswa SMAN 12 Kota Bekasi. Manfaat penelitian ini dapat memberikan informasi bagi remaja putri khususnya siswi SMAN 12 kota Bekasi mengenai fast food, tingkat stress, dan siklus menstruasi.

\section{Metode Penelitian}

Penelitian ini menggunakan desain cross sectional untuk mengetahui hubungan kebiasaan makan fast food dan tingkat stress terhadap siklus menstruasi pada siswi SMAN 12 Kota Bekasi. Desain cross sectional adalah penelitian non eksperimental untuk mempelajari dinamika korelasi antara faktorfaktor resiko dengan efek, dan menggunakan cara pendekatan obsevasi atau pengumpulan data sekaligus pada waktu yang sama (Notoatmodjo, 2010).

Penelitian ini di lakukan di SMAN 12 Kota Bekasi yang berlokasi di Jalan Raya I Gusti Ngurah Rai, RT.008/RW.010, Kranji, Kec. Bekasi Barat, Kota Bekasi, Jawa Barat 17135. Waktu penelitian di laksanakan pada bulan Desember 2020 - Januari 2021. Teknik pengambilan sampel ini menggunakan metode simple random sampling. Simple random 
sampling adalah teknik pengambilan sampel dari anggota populasi yang dilakukan secara acak tanpa memperhatikan strata yang ada dalam populasi (Salasia et al., 2011).

\section{Hasil dan Pembahasan}

\section{A. Hasil Penelitian}

Pada bab ini diuraikan hasil penelitian tentang "Hubungan konsumsi fast food dan stres terhadap siklus menstruasi pada siswi SMAN 12 Kota Bekasi" pada tanggal 13 Januari 2021 dengan responden 66 orang remaja putri. Hasil penelitian ini dikelompokan menjadi 3 bagian yaitu gambaran tempat penelitian, analisis univariat, dan analisis bivariat. Penelitian ini di lakukan di SMAN 12 Kota Bekasi. SMAN 12 Kota Bekasi merupakan sekolah yang berlokasi di Jalan Raya I Gusti Ngurah Rai, RT.008/RW.010, Kranji, Kec. Bekasi Barat, Kota Bekasi, Jawa Barat 17135. SMAN 12 Kota Bekasi memiliki 3 jurusan yaitu IPA, IPS, dan Bahasa, untuk setiap kelas X, XI, XII ada 5 kelas jurusan IPA, 4 kelas jurusan IPS, dan 1 kelas untuk Bahasa. Penelitian ini dilaksanakan pada bulan januari 2021. Hasil penelitian ini diperoleh melalui pengumpulan data angket mengenai frekuensi konsumsi fast food, tingkat stres dan siklus menstruasi yang dilakukan secara daring. Hasil penyebaran instrumen akan dijadikan sebagai analisis data untuk mengetahui korelasi antara frekuensi konsumsi fast food dan tingkat stres dengan siklus menstruasi.

1. Analisa Univariat

Pada analisis univariat ini di lakukan untuk mengetahui sebaran data konsumsi fastfood, tingkat stress dan siklus menstruasi.
Tabel 1

Siklus Menstruasi

\begin{tabular}{llc}
\hline \multicolumn{1}{c}{ Siklus Menstruasi } & N & \% \\
\hline Normal & 28 & 42,4 \\
\hline Tidak Normal & 38 & 57,6 \\
\hline \multicolumn{1}{c}{ Total } & $\mathbf{6 6}$ & $\mathbf{1 0 0}$ \\
\hline
\end{tabular}

Tabel 1 menunjukan bahwa data siklus menstruasi paling banyak adalah tidak normal yaitu sebanyak 38 responden atau 57,6 \% dari total 66 responden. selain itu, responden yang mengalami siklus menstruasi normal yaitu sebanyak 28 responden atau $42,4 \%$.

Tabel 2

Tingkat Stres

\begin{tabular}{ccc}
\hline Tingkat Stres & $\mathbf{N}$ & $\mathbf{\%}$ \\
\hline Stres Ringan & 13 & 19,7 \\
\hline Stres Berat & 53 & 80,3 \\
\hline Total & $\mathbf{6 6}$ & $\mathbf{1 0 0}$ \\
\hline
\end{tabular}

Berdasarkan tabel 2 diatas, hasil yang di dapat sebanyak $80,3 \%$ responden mengalami stres berat, dan $19,7 \%$ mengalami stres ringan.

Tabel 3

Konsumsi Fast food

\begin{tabular}{|c|c|c|}
\hline Konsumsi Fast Food & $\mathbf{N}$ & \\
\hline Jarang & 24 & 36,4 \\
\hline Sering & 42 & 63,6 \\
\hline Total & 66 & 100 \\
\hline
\end{tabular}

Sebaran konsumsi fast food pada siswi kelas $\mathrm{X}$ dan $\mathrm{XI}$ menunjukkan bahwa 24 responden $(36,4 \%)$ dikategori jarang. Selain itu, terdapat 42 responden $(63,6 \%)$ termasuk kedalam kategori sering.

2. Analisis Bivariat

Analisis bivariat ini merupakan analisis yang di lakukan untuk mengetahui hubungan antara 2 variabel yang di teliti 
(konsumsi fast food dan stres) dengan siklus menstruasi pada siswi SMAN 12 Kota Bekasi.

\section{Tabel 4}

Hubungan Konsumsi Fast Food dengan Siklus Menstruasi

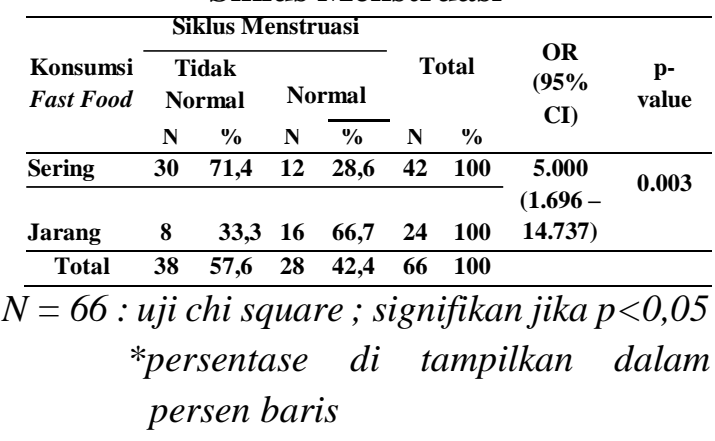

Berdasarkan tabel 4 menunjukan hasil analisis hubungan antara konsumsi fast food dengan siklus menstruasi diketahui bahwa dari 30 responden $(71,4 \%)$ yang sering mengkonsumsi fast food mengalami siklus menstruasi tidak normal. untuk yang konsumsi fast food sering dan memiliki siklus menstruasi normal sebanyak 12 responden $(28,6 \%)$, sedangkan responden dengan konsumsi fast food jarang terdapat 16 responden $(66,7 \%)$ yang memiliki siklus menstruasi normal. untuk konsumsi fast food jarang dan memiliki siklus menstruasi tidak normal terdapat 8 responden $(33,3 \%)$. Hasil uji statistik mendapatkan nilai $p$-value $=0.003$ yang dimana artinya ada hubungan yang signifikan antara konsumsi fast food dengan siklus menstruasi. Dengan nilai OR $(95 \%$ CI) sebesar 5.0 yang berarti siswi dengan konsumsi fast food sering beresiko 5 kali lebih besar memiliki siklus menstruasi yang tidak normal dibanding dengan siklus menstruasi normal.
Tabel 5

Hubungan Tingkat Stres dengan Siklus

Menstruasi

\begin{tabular}{|c|c|c|c|c|c|c|c|c|}
\hline \multirow{3}{*}{$\begin{array}{c}\text { Tingkat } \\
\text { Stres }\end{array}$} & \multicolumn{4}{|c|}{ Siklus Menstruasi } & \multirow{2}{*}{\multicolumn{2}{|c|}{ Total }} & \multirow{3}{*}{$\begin{array}{c}\text { OR } \\
(\mathbf{9 5} \% \\
\text { CI })\end{array}$} & \multirow{3}{*}{$\begin{array}{l}\text { p- } \\
\text { value }\end{array}$} \\
\hline & \multicolumn{2}{|c|}{$\begin{array}{c}\text { Tidak } \\
\text { Normal } \\
\end{array}$} & \multicolumn{2}{|c|}{ Normal } & & & & \\
\hline & $\mathbf{N}$ & $\%$ & $\mathbf{N}$ & $\%$ & $\mathbf{N}$ & $\%$ & & \\
\hline $\begin{array}{l}\text { Stres } \\
\text { tinggi }\end{array}$ & 38 & 66 & 18 & 34 & 53 & 100 & \multirow{2}{*}{$\begin{array}{c}6,481 \\
(1,583- \\
26,545)\end{array}$} & \multirow[t]{2}{*}{0,005} \\
\hline $\begin{array}{l}\text { Stres } \\
\text { rendah }\end{array}$ & 3 & 23,1 & 10 & 76,9 & 13 & 100 & & \\
\hline Total & 41 & 42,4 & 28 & 57,6 & 66 & \multicolumn{2}{|l|}{100} & \\
\hline \multicolumn{9}{|c|}{66 : uji chi square; signifikan jika $p<0,05$} \\
\hline \multicolumn{5}{|c|}{$\begin{array}{l}\text { *persentase } \\
\text { persen baris }\end{array}$} & \multicolumn{3}{|c|}{ tampilkan } & alam \\
\hline
\end{tabular}

Berdasarkan tabel 5 dari hasil hubungan tingkat stres dengan siklus menstruasi dapat diketahui bahwa diantara responden dengan tingkat stres tinggi terdapat 38 responden $(66 \%)$ yang memiliki siklus menstruasi yang tidak normal. Untuk tingkat stres tinggi dengan siklus menstruasi normal sebanyak 18 responden (34\%).

Sementara itu, 10 responden $(76,9 \%)$ dengan tingkat stres rendah memiliki siklus menstruasi normal. Untuk tingkat stres rendah dengan siklus menstruasi tidak normal terdapat 3 responden $(23,1 \%)$. Hasil uji chi-square menghasilkan $p$-value $=0,005$ maka ada hubungan yang signifikan antara tingkat stres dengan siklus menstruasi pada siswi SMAN 12 Kota Bekasi. Dari hasil analisis di peroleh nilai OR $(95 \% \mathrm{CI})$ adalah 6,4 yang berarti bahwa siswi dengan tingkat stres tinggi beresiko 6,4 kali lebih besar memiliki siklus menstruasi tidak normal dibanding dengan yang memiliki siklus menstruasi normal.

B. Pembahasan

1. Analisis Univariat

a. Konsumsi Fast Food

Berdasarkan hasil penelitian pada siswi SMAN 12 Kota Bekasi didapatkan sebagian besar responden memiliki kategori konsumsi fast 
food yang sering sebanyak 63,6\%. Sedangkan responden yang memiliki kategori konsumsi fast food jarang sebanyak 36,4\%. Hal ini sejalan dengan (Nilsen et al., 2008) menunjukkan bahwa sebesar 69\% orang Indonesia mengkonsumsi fast food. Penelitian (Astuti \& Maggiolo, 2014) juga menunjukkan bahwa yang paling banyak mengkonsumsi fast food adalah dari kalangan remaja.

Fast food banyak di gemari kalangan remaja dikarenakan mudah didapatkan dan praktis. Hal ini sejalan dengan teori (Daulay \& Purwati, 2020) yang menyatakan bahwa fast food disukai karena kepraktisannya dari waktu dan rasanya dengan harga yang terjangkau. Ini semua terkait dengan gaya hidup yang mengarah pada modernitas. Disadari atau tidak, perkembangan zaman akan merubah gaya hidup (lifestyle), pola hidup (life term) dan kebutuhan (needs). Selain itu pada penelitian (Kristianti et al., 2016) menemukan bahwa karena kesibukan orang tua terutama ibu yang tidak sempat menyiapkan makanan di rumah, remaja cenderung makan makanan siap saji, oleh karena itu makanan siap saji menjadi salah satu alternatif. Kondisi sosial ekonomi dan kepraktisan untuk menyediakan makanan dan waktu. Saat ini, inilah alasan yang mempengaruhi pertumbuhan konsumsi fast food. Menurut (Lubis, 2019) fast food yang dimaksud mengacu pada makanan yang dapat diperoleh dan disajikan dalam waktu yang singkat, seperti ayam goreng, hamburger, dan pizza.

Remaja memiliki pola makan tidak teratur dan berisiko mengalami masalah gizi. Kebiasaan pola makan remaja saat ini, seperti tidak melakukan sarapan pagi, makan tidak teratur, sering mengkonsumsi fast food, dan jarang makan sayur atau buah. Hal tersebut dapat mengakibatkan asupan makanan yang tidak memenuhi kebutuhan dan keseimbangan gizi yang dapat mengakibatkan terjadinya gizi kurang atau gizi lebih (Irianto et al., 2014).

b. Tingkat Stres

Berdasarkan tabel 2 di ketahui bahwa responden yang memiliki tingkat stres ringan sejumlah 13 responden $(19,7 \%)$ dan tang memiliki tingkat stres tinggi sebanyak 53 responden (80,3\%). Berdasarkan survei peneliti, menurut data umum, responden berusia 66 siswa (100\%) berusia 15-17 tahun. Usia sangat erat kaitannya dengan kemampuan seseorang terhadap stres. Selama masa ini remaja sangat beresiko terhadap stres, dan emosinya sangat kuat, tetapi dari awal pubertas (remaja awal) hingga akhir masa pubertas (remaja akhir) terjadi perubahan perilaku emosinya yang membaik, dan dapat mengendalikan stres dengan lebih baik, sehingga dapat mencegah stres yang berkelanjutan. Hal tersebut sesuai dengan teori (Sa'id \& Mrayyan, 2015). Pada saat remaja mereka telah mengalami banyak perubahan kognitif, emosional, dan sosial, mereka dapat berfikir lebih kompleks, sehingga mereka dapat mengontrol terjadinya stres dan mencegah stres yang berkepanjangan.

$$
\begin{array}{lr}
\text { Terjadinya perubahan besar } \\
\text { seperti itu r umumnya } \\
\text { membingungkan remaja yang pernah }
\end{array}
$$


mengalami perubahan tersebut. Karenanya, remaja rentan terhadap stres karena mengalami banyak perubahan pada dirinya. Selain itu, remaja merupakan tahap awal dari masa dewasa, oleh karena itu remaja dituntut untuk melakukan tugastugas perkembangannya dengan benar dan menjalankan peran baru menuju masa dewasa. Tuntutan ini biasanya membingungkan remaja karena masih dalam tahap adaptasi dan mencari identitas atau jati diri (Widyastuti, 2009). Pada siswi di SMAN 12 Kota Bekasi sebagian besar mengalami stress tingkat tinggi (berat) dikarenakan pembelajaran daring yang mulai membosankan. Hasil penelitian ini sejalan dengan penelitian yang menunjukkan bahwa metode pengajaran tenaga pengajar mempunyai pengaruh yang signifikan terhadap tingkat stres (Hayati \& Agustin, 2020). Menurut (Yuanita, 2020) juga mengemukakan bahwa kebutuhan untuk menguasai berbagai ilmu dan keterampilan dalam waktu yang terbatas dapat menimbulkan stres pada siswa. Tingkat stres ini terkait dengan kehidupan sehari-hari seperti tugas, ujian, kurangnya waktu luang, dan tekanan akademik yang penuh persaingan dalam lingkungan seharihari juga menjadi penyebab stres (Sohail, 2013).

c. Siklus Menstruasi

Berdasarkan hasil penelitian di atas dapat di lihat dari 66 orang siswi kelas X - IX SMAN 12 Kota Bekasi yang mengalami siklus menstruasi yang teratur sebanyak normal yaitu sebanyak 28 responden atau $42,4 \%$. Selain itu sebanyak 38 responden atau $57,6 \%$ dari total 66 responden mengalami siklus menstruasi tidak normal.

Siklus menstruasi yang teratur adalah rangkaian siklus menstruasi yang saling mempengaruhi, yang terjadi pada saat yang sama ketika perdarahan uterus periodik dimulai sekitar 14 hari setelah ovulasi secara berkala karena pelepasan endometrium uterus. Perbedaan lamanya siklus menstruasi antar wanita biasanya disebabkan oleh ketidakseimbangan hormon esterogen, progesteron, LH dan FSH yang disebabkan oleh penyakit, status gizi, konsumsi fast food maupun stres (Pebrina, 2021).

Menurut penelitian (Rezandy, 2019) faktor risiko gangguan menstruasi adalah berat badan, aktivitas fisik, stres, pola makan, paparan lingkungan dan kondisi kerja, interaksi sosial dan lingkungan, dan gangguan endokrin. Selain status gizi, masih banyak faktor lain yang mempengaruhi siklus menstruasi, namun karena keterbatasan metode pengukuran dan alokasi waktu, penelitian ini tidak mengungkap semua faktor secara rinci.

2. Analisis Bivariat

a. Hubungan Konsumsi Fast Food dengan Siklus Menstruasi siswi SMAN 12 Kota Bekasi.

Berdasarkan hasil penelitian menunjukan hasil analisis hubungan antara konsumsi fast food dengan siklus menstruasi diketahui bahwa dari 30 responden $(71,4 \%)$ yang sering mengkonsumsi fast food mengalami siklus menstruasi tidak normal. untuk yang konsumsi fast food sering dan memiliki siklus menstruasi normal sebanyak 12 responden $(28,6 \%)$. sedangkan 
responden dengan konsumsi fast food jarang terdapat 16 responden $(66,7 \%)$ yang memiliki siklus menstruasi normal. untuk konsumsi fast food jarang dan memiliki siklus menstruasi tidak normal terdapat 8 responden $(33,3 \%)$. Hasil uji statistik mendapatkan nilai $\mathrm{p}$-value $=0.003$ yang dimana artinya ada hubungan yang signifikan antara konsumsi fast food dengan siklus menstruasi pada siswi SMAN 12 Bekasi.

Menurut (Rezandy, 2019), menstruasi adalah perdarahan yang berasal dari uterus yang disebabkan pelepasan endometrium akibat hormon ovarium (esterogen dan progesteron) mengalami penurunan, (Boulant et al., 2016) menjelaskan bahwa menstruasi merupakan kondisi yang normal dan setiap wanita dalam keadaan yang normal kesehatannya. Namun saat menstruasi, mungkin ada banyak hal yang membuat diri kita atau keluarga khawatir. Meski tidak semua wanita akan mengalami kondisi yang sama. Penelitian ini sejalan dengan penelitian yang dilakukan oleh (Lubis, 2019) dengan judul hubungan konsumsi fast food dengan siklus menstruasi pada siswi kelas $\mathrm{X}$ yayasan perguruan panca Medan tahun 2018, bahwa adanya korelasi antara konsumsi fast food dengan siklus menstruasi dimana dari 64 responden $(95.5 \%)$ yang sering mengkonsumsi fast food yang mengalami siklus menstruasi teratur sebanyak 17 responden $(25.4 \%)$ dan yang tidak teratur sebanyak 47 responden $(70.1 \%)$. Sedangkan responden yang jarang mengonsumsi fast food yakni 3 responden $(4.5 \%)$ memiliki siklus menstruasi teratur. Hal ini di sebabkan karena kurangnya pengetahuan siswi ataupun remaja tentang kandungan fast food. Beberapa kandungan yang tidak baik untuk kualitas kecukupan nutrisi bagi kesehatan remaja putri. Kandungan makanan siap saji yang berlebihan tidak baik untuk kesehatan remaja putri.

Penelitian ini sejalan juga dengan penelitian yang berjudul "Hubungan Konsumsi Fast Food Remaja dengan Siklus Menstruasi" yang dilakukan oleh Sri Wahyuni di AKBID Muhammadiyah Aceh Tahun 2013. Ada remaja putri yang sering mengonsumsi makanan cepat saji ini dan mengalami siklus menstruasi yang tidak teratur, ini karena kandungan makanan tersebut akan mempengaruhi fungsi beberapa enzim yang dibutuhkan untuk hormon pertumbuhan dalam tubuh. tetapi, sebagian remaja sering makan fast food, namun siklus menstruasinya teratur. Hal tersebut dapat terjadi karena para remaja putri tersebut mungkin masih bisa menyeimbangkan konsumsi antara makanan fast food dan makanan sehat, selain itu ditambah dengan adanya aktivitas rutin seperti olahraga.

Fast food dalam penelitian ini berpengaruh secara eksternal terhadap siklus menstruasi. Fast food adalah makanan yang mempunyai nilai gizi rendah. Zat gizi mempunyai nilai yang sangat penting, yaitu untuk memelihara proses tubuh dalam pertumbuhan dan perkembangan yang sehat, terutama bagi remaja yang masih dalam pertumbuhan. Keadaan gizi remaja putri dapat berpengaruh terhadap pertumbuhan fisik termasuk siklus menstruasi. Dengan 
demikian perbedaan siklus haid sangat ditentukan berdasarkan keadaan status gizi. Semakin bagus status gizinya, maka akan semakin cepat usia menarche. Kebiasaan remaja untuk makan tidak teratur juga berpengaruh, seperti tidak sarapan, mengkonsumsi fast food, dan melakukan diet yang tidak terkendali.

b. Hubungan Tingkat Stres dengan Siklus Menstruasi siswi SMAN 12 Kota Bekasi.

Dari hasil di atas dapat diketahui bahwa diantara responden dengan tingkat stres tinggi terdapat 38 responden (66\%) yang memiliki siklus menstruasi yang tidak normal. Untuk tingkat stres tinggi dengan siklus menstruasi normal sebanyak 18 responden (34\%). Sementara itu, 10 responden $(76,9 \%)$ dengan tingkat stres rendah memiliki siklus menstruasi normal. Untuk tingkat stress rendah dengan siklus menstruasi tidak normal terdapat 3 responden $(23,1 \%)$. Hasil uji chisquare menghasilkan p-value = 0,005 maka ada hubungan yang signifikan antara tingkat stres dengan siklus menstruasi pada siswi SMAN 12 Kota Bekasi.

Berdasarkan hasil penelitian ini sesuai dengan penelitian (Allotey et al., 2014) dengan judul "hubungan tingkat stress terhadap siklus menstruasi pada remaja SMA di lingkungan Deli 2014” yang menyatakan bahwa ada hubungan yang sangat signifikan diantara tingkat stress dengan siklus menstruasi, dari 40 responden yang mengalami stress berat dan siklus menstruasi tidak normal sebesar $60 \%$.
Berdasarkan hasil penelitian ini, sejalan dengan penelitian Sekar (Pinasti \& Anggraini, 2012), "Hubungan Tingkat Stres Siswa Kelas II di SMAN 1 Kendal dengan Siklus Menstruasi”, nilai p: 0,012 (p $<0,05)$. Menunjukkan tingkat stres dan siklus menstruasi. Ada hubungan antara, semakin tinggi tingkat stres, semakin tinggi kemungkinan gangguan siklus menstruasi. Dalam kondisi stres, amigdala di sistem limbik diaktifkan. Sistem ini merangsang hipotalamus untuk melepaskan hormon yang disebut Corticotrofik Realising Hormone (CRH). Hormon secara langsung menghambat sekresi GnRH di hipotalamus di nukleus arkuata, dan proses ini terjadi dengan menambahkan sekresi opioid endogen. Kadar $\mathrm{CRH}$ yang meningkat merangsang pelepasan hormon endorfin dan kortikotropin ke dalam darah. Hormon-hormon ini secara langsung menyebabkan penurunan kadar $\mathrm{GnRH}$, dan stres dapat menyebabkan gangguan siklus menstruasi.

Stres merupakan faktor yang mempengaruhi siklus menstruasi, pada keadaan stres yang di sebabkan oleh stresor terjadi pengaktifan HPA aksis, mengakibatkan hipotalamus menyekresikan (Corticotropic Releasing Hormone) CRH. CRH ini mempunyai pengaruh negatif yaitu menghambat sekresi GnRH hipotalamus dari tempat produksinya di nucleus arkuata, ketidakseimbangan $\mathrm{CRH}$ memiliki pengaruh terhadap penekanan fungsi reproduksi wanita sewaktu stres. Sekresi CRH ini akan merangsang pelepasan (Adenocorticotropnc Hormon) ACTH oleh hipofisis 
anterior yang selanjutnya ACTH akan merangsang kelenjar adrenal untuk menyekresikan kortisol. Kortisol berperan dalam menghambat sekresi LH oleh pusat aktivitas otak dengan cara menghambat respon hipofisis anterior terhadap GnRH (Breen \& Karsch, 2004).

\section{Kesimpulan}

Berdasarkan tujuan penelitian tentang "Hubungan Konsumsi Fast Food dan Stres Terhadap Siklus menstruasi pada siswi di SMAN 12 Bekasi" dapat disimpulkan pertama persentase konsumsi fast food di kategori sering sebanyak $63,6 \%$. Sedangkan pada kategori jarang sebanyak 36,4\%. Kedua persentase tingkat stres pada kategori stres ringan sebesar $(19,7 \%)$ dan untuk kategori stres tinggi sebesar (80,3\%). Ketiga persentase pada siklus menstruasi tidak normal sebanyak $(57,6 \%)$ dari total 66 responden dan yang mengalami siklus menstruasi normal sebanyak $(42,4 \%)$. Keempat terdapat hubungan yang signifikan antara konsumsi fast food dan siklus menstruasi pada siswi dengan p-value 0,003 dan OR yang di dapat yaitu 5.0 yang berarti berarti siswi SMAN 12 Kota Bekasi dengan konsumsi fast food sering beresiko 5 kali lebih besar memiliki siklus menstruasi yang tidak normal dibanding dengan siklus menstruasi normal. Dan terdapat hubungan yang signifikan antara tingkat stres dengan siklus menstruasi pada siswi SMAN 12 Kota Bekasi dengan p-value 0,005 dan OR 6,4 yang berarti bahwa siswi dengan tingkat stres tinggi beresiko 6,4 kali lebih besar memiliki siklus menstruasi tidak normal dibanding dengan yang memiliki siklus menstruasi normal.

\section{BIBLIOGRAFI}

Abdullah, M., Difranzo, A., Rajaraman, A., Tait, T. M. P., Tanedo, P., \& Wijangco,
A. M. (2014). Hidden On-Shell Mediators For The Galactic Center $\Gamma$ Ray Excess. Physical Review D, 90(3), 35004. Google Scholar

Allotey, P., Reidpath, D. D., Devarajan, N., Rajagobal, K., Yasin, S., Arunachalam, D., Debora Imelda, J., Soyiri, I., Davey, T., \& Jahan, N. (2014). Cohorts And Community: A Case Study Of Community Engagement In The Establishment Of A Health And Demographic Surveillance Site In Malaysia. Global Health Action, 7(1), 23176. Google Scholar

Astuti, N., \& Maggiolo, F. (2014). SingleTablet Regimens In Hiv Therapy. Infectious Diseases And Therapy, 3(1), 1-17. Google Scholar

Banowati, L., Nugraheni, N., \& Puruhita, N. (2011). Risiko Konsumsi Western Fast Food Dan Kebiasaan Tidak Makan Pagi Terhadap Obesitas Remaja Studi Di Sman 1 Cirebon. Media Medika Indonesiana, 45(2), 118-124. Google Scholar

Boulant, N., Wu, X., Adriany, G., Schmitter, S., Uğurbil, K., \& Van De Moortele, P. (2016). Direct Control Of The Temperature Rise In Parallel Transmission By Means Of Temperature Virtual Observation Points: Simulations At 10.5 Tesla. Magnetic Resonance In Medicine, 75(1), 249-256. Google Scholar

Breen, K. M., \& Karsch, F. J. (2004). Does Cortisol Inhibit Pulsatile Luteinizing Hormone Secretion At The Hypothalamic Or Pituitary Level? Endocrinology, 145(2), 692-698. Google Scholar

Daulay, M., \& Purwati, K. (2020). Hubungan Penggunaan Kb Suntik Depo Provera 3 Bulan Terhadap Kadar Hb Pada Wus Wanita Usia Subur Di Bpm (Bidan Praktek Mandiri) Nuni Nuraeni Kelurahan Padasuka Ciomas Kabupaten 
Bogor. Zona Kedokteran: Program Studi Pendidikan Dokter Universitas Batam, 9(2), 80-87. Google Scholar

Hayati, S., \& Agustin, S. (2020). FaktorFaktor Yang Berhubungan Dengan Dismenore Pada Remaja Di Sma Pemuda Banjaran Bandung. Jurnal Keperawatan Bsi, 8(1), 132-142. Google Scholar

Irianto, J., Ramaswamy, G., Serra, R., \& Knight, M. M. (2014). Depletion Of Chondrocyte Primary Cilia Reduces The Compressive Modulus of Articular Cartilage. Journal of Biomechanics, 47(2), 579-582. Google Scholar

Kristianti, S., Wibowo, T. A., \& Winarsih, W. (2016). Hubungan Anemia Dengan Siklus Menstruasi Pada Remaja Putri Di Sma Negeri 1 Imogiri, Bantul, Yogyakarta Tahun 2013. Jurnal Studi Pemuda, 3(1), 33-38. Google Scholar

Larasati, T. A., \& Alatas, F. (2016). Dismenore Primer Dan Faktor Risiko Dismenore Primer Pada Remaja. Jurnal Majority, 5(3), 79-84. Google Scholar

Lubis, L. R. (2019). Hubungan Konsumsi Makanan Siap Saji (Fast Food) Dengan Siklus Menstruasi Siswi Kelas Ix Di Smp Yayasan Perguruan Panca Budi Medan Tahun 2018. Institut Kesehatan Helvetia. Google Scholar

Nilsen, F., Cottier, F., Skogseth, R., \& Mattsson, S. (2008). Fjord-Shelf Exchanges Controlled By Ice And Brine Production: The Interannual Variation Of Atlantic Water In Isfjorden, Svalbard. Continental Shelf Research, 28(14), 1838-1853. Google Scholar

Notoatmodjo, S. (2010). Ilmu Perilaku Kesehatan. Penerbit Rineka Cipta. Google Scholar

Pebrina, M. (2021). Hubungan Status Gizi Dengan Keteraturan Siklus Menstruasi Pada Siswi Remaja Di Sma N 12 Padang Tahun 2015. Jurnal Kesehatan Medika Saintika, 7(2). Google Scholar
Perry, B. D. (2009). Examining Child Maltreatment Through A Neurodevelopmental Lens: Clinical Applications of The Neurosequential Model Of Therapeutics. Journal Of Loss And Trauma, 14(4), 240-255. Google Scholar

Pinasti, S., \& Anggraini, M. T. (2012). Hubungan Antara Tingkat Stres Dengan Siklus Menstruasi Pada Siswi Kelas 2 Di Sma N 1 Kendal. Jurnal Kedokteran Muhammadiyah, 1(2). Google Scholar

Prihatanti, N. R. (2010). Hubungan Antara Tingkat Kecemasan Dengan Kejadian Dismenorea Pada Remaja Putri Di Pondok Pesantren Imam Syuhodo Polokarto Sukoharjo. Surakarta: Universitas Sebelas Maret. Google Scholar

Purwoastuti, E. (2009). Waspadai Gangguan Rematik. Kanisius. Yogyakarta. Google Scholar

Rezandy, D. A. (2019). Efektivitas Mengkonsumsi Buah Kurma Untuk Mencegah Penurunan Hemoglobinsaat Menstruasi Pada Remaja Putri Di Pondok Pesantren Raudlatul Qur'an Kota Metro. Poltekkes Tanjungkarang. Google Scholar

Sa'id, A. N., \& Mrayyan, M. (2015). Do Not Resuscitate: An Argumentative Essay. Palliat Med Care, 2(1), 1-5. Google Scholar

Salasia, S. I. O., Tato, S., Sugiyono, N., Ariyanti, D., \& Prabawati, F. (2011). Genotypic Characterization Of Staphylococcus Aureus Isolated From Bovines, Humans, And Food In Indonesia. Journal of Veterinary Science, 12(4), 353. Google Scholar

Sohail, N. (2013). Stress And Academic Performance Among Medical Students. $J$ Coll Physicians Surg Pak, 23(1), 67-71. Google Scholar 
Widyastuti, E. S. A. (2009). Personal Dan

Sosial Yang Mempengaruhi Sikap

Remaja Terhadap Hubungan Seks

Pranikah. Jurnal Promosi Kesehatan

Indonesia, 4(2), 75-85. Google Scholar

Yuanita, R. N. (2020). Hubungan Antara Stres

Dengan Siklus Menstruasi Pada Siswi

Kelas V Dan Vi Sdn Kebonagung Ploso

Jombang. Stikes Insan Cendekia Medika

Jombang. Google Scholar

\section{Copyright holder:}

Benefita Rahma (2021)

First publication right:

Jurnal Health Sains

This article is licensed under:

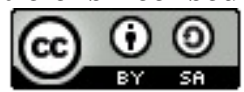

